\title{
RESEARCH ON COPPER-67 SEPARATION OBTAINED BY PHOTO-NUCLEAR FROM ZINC OF NATURAL COMPOSITION
}

\author{
O.I. Azarov, V.O. Bocharov, O.F. Stoyanov \\ National Science Center "Kharkov Institute of Physics and Technology”, Kharkiv, Ukraine \\ E-mail: bocharov@kipt.kharkov.ua
}

In the world, it is planned to produce promising for the manufacture of radiopharmaceuticals of radioisotope copper-67 by the reaction of its production from zinc-68 under the influence of $\gamma$-radiation on an electron accelerator. The next major issue is the separation of copper and zinc. Extraction, ion exchange and thermal distillation of zinc have already been studied in detail. Co-precipitation of copper with low zinc and thermal distillation of organic compounds of metals is promising.

PACS: $8255 .+\mathrm{e}$

\section{INTRODUCTION}

Copper-67 is a $\beta$-emitter with an average energy of $141 \mathrm{keV}$ and a half-life of $61.8 \mathrm{~h}$, accompanied by $\gamma$ radiation of 91,93 , and $185 \mathrm{keV}$, it is produced by the reaction of ${ }^{68} \mathrm{Zn}(\gamma, \mathrm{p}){ }^{67} \mathrm{Cu}$ on the electron accelerator at their energy $30 \ldots 60 \mathrm{MeV}$ and even $25 \mathrm{MeV}$. The use of an electron accelerator to produce copper-67 reduces the amount of radioactive waste. Copper-67 and its decay product ${ }^{67} \mathrm{Zn}$ are not acutely toxic. These characteristics make it suitable for use in diagnosis and treatment. But there are still no methods of industrial production of this isotope.

Almost comprehensive data on copper production at that time, including the separation of copper and zinc, were given in the article [1]. In the following years, Ehst and his staff developed a means of thermal separation of copper from irradiated zinc [2] at an energy of $40 \ldots 50 \mathrm{MeV}$ with a tantalum converter. Distillation of zinc was carried out under vacuum at $500 \ldots 700^{\circ} \mathrm{C}$. In this way, a copper concentrate, which needs further purification, was obtained. Significant requirements for the material of the vessel from which the distillation was carried out take place, it is necessary that it does not contaminate metals and they do not stick to it, and also have a reasonable price. Only fused aluminum oxide (leucosapphire) meets these requirements. The sophisticated equipment used for thermal separation of copper from zinc ingot inhibits the introduction of copper-67 isotope for the manufacture of radiopharmaceuticals. If you think about it, you can suggest other ways of separating ultra-low concentrations of copper from zinc. The classical methods are liquid extraction with organic solvents and ion exchange. In these two ways, extraction is easier, since ion exchange requires more labor and in the end we get the final product distributed in a large volume of water. Consideration should be given to such methods as the co-precipitation of copper with zinc compounds and the distillation of our metals in the form of organic compounds.

\section{LIQUID COPPER EXTRACTION}

Some authors have used sodium diethyldithiocarbamate (NaDTC) to extract copper from zinc [3]. From the solution of zinc salts copper is extracted into carbon tetrachloride at $\mathrm{pH} 4.5 \ldots 5.5$, at such a $\mathrm{pH}$ is not formed the basic zinc salts. The molar ratio of copper: NaDTC 1: 3 is sufficient for complete extraction of copper from a solution containing $20 \mathrm{~g} / \mathrm{l}$ zinc. After dissolving a zinc sample $(\sim 20 \mathrm{~g})$ containing $2 \ldots 15 \mu \mathrm{g}$ of copper, the solution in the separating funnel is neutralized with ammonia to $\mathrm{pH} 4.5 \ldots 5,20 \mathrm{ml}$ of a $20 \%$ solution of ammonium citrate for masking iron, $1 \mathrm{ml}$ of $0.1 \%$ aqueous $\mathrm{NaDTC}$ solution and $10 \mathrm{ml} \mathrm{CCl}_{4}$, vigorously shaken for $2 \mathrm{~min}$. In the second work of the same authors [4] it is stated that when the content of copper in zinc $1 \cdot 10^{-5} \%$ even $1.5 \ldots 2$-fold excess of NaDTC against stoichiometric is sufficient. The extraction time is only $10 \mathrm{~min}$.

The above quoted authors did not indicate that it extracts a certain amount of zinc with NaDTC copper. In [5] it is shown that even all reagents contain copper, and when determining $10^{-7} \%$ of copper in zinc it is necessary to further clean the reagents from copper. For example, the original $0.2 \mathrm{M}$ NaDTC solution was shaken with chloroform. The difference with previous publications $[3,4]$ in the use of chloroform (instead of carbon tetrachloride) as solvent and extraction from slightly acidic medium ( $\mathrm{pH} 4.0 \ldots 4.5)$ exists.

Dithizone is also widely used as a $0.01 \ldots 0.001 \%$ solution in carbon tetrachloride only. In one of the pioneering works [6], radioactive copper was extracted with a $0.001 \%$ solution at a $\mathrm{pH}$ of $1 . .1 .2$ three times, the combined extracts were washed with $0.1 \mathrm{M}$ hydrochloric acid, the extract was evaporated, and copper dithizonate in the dry residue was destroyed at $500^{\circ} \mathrm{C}$. The reference [1] cites a work in which the accompanying zinc after the destruction of dithizonate in acidic medium with hydrogen peroxide was absorbed by a strong basic anion exchanger in the chloride form (regenerated $6 \mathrm{M} \mathrm{HCl}$ ).

In the work with copper also used diantipyrilmethane [7]. When the acidity of the aqueous solution of $2.5 \ldots 3 \mathrm{M} \mathrm{HCl}$ extract $\mathrm{Cu}^{2+}$ does not exceed $10 \%$, so we used chloroform extraction of the complex of monovalent copper (after reduction of $\mathrm{Cu}^{2+}$ ), which completely goes into the organic phase in a wide range of acidity of the medium: from 0.5 to $6 \mathrm{M} \mathrm{HCl}$, the concentration of chloride ions should not be lower than 2...3 M, the extraction is carried out twice.

Re-extraction is carried out with alkaline water mixed with hydrogen peroxide to oxidize copper. In the second work of the analysts of this school [8] it was found that $99 \%$ of copper is extracted from iodide solutions $(3 \%$ by KI) with 5 -fold excess of diantipyrilmethane. In this case, the monovalent copper is also extracted, since the iodide ion is a strong reducing agent. It is stated that zinc interferes with the extraction 
of copper from the chloride system, probably bromides and iodides will also interfere with the presence of zinc. We used diantipyrylpropylmethane (DAPM) derivative of diantipyrylmethane to extract copper. Our analysis showed that $1 \mathrm{~g}$ of zinc brand "pure for analysis" contains $15.4 \mu \mathrm{g}$ of copper or $1.54 \cdot 10^{-3} \%$, in some cases, the copper content reached $9 \cdot 10^{-3} \%$. Based on general considerations and previous experiments, we chose following the extraction conditions: zinc concentration up to $2 \mathrm{M}$, sulfuric acid $1 \mathrm{M}$, potassium iodide $0.1 \mathrm{M}$, DAPM $0.02 \mathrm{M}$ in chloroform. Usually used volumes of aqueous solution and chloroform with reagent. From chloroform, copper was extracted with slightly alkaline water with hydrogen peroxide as above [7] and the $\mathrm{pH}$ of the water should not be below 6. But the tests showed that a considerable amount of zinc is extracted with the copper, even exceeding the amount of copper many times over. Copper is probably extracted from the sulfuric acid medium in the form of an ionic associate (LH) $\left[\mathrm{CuI}_{2}\right]$, where $\mathrm{LH}^{+}$is a protonated DAPM molecule. Apparently, besides such an associate, charged particles with copper are formed, which do not pass into the organic phase. In a separate experiment, the copper content of the aqueous reextract was $0.024 \mathrm{mg} / \mathrm{l}$ and at the same time zinc in the same sample was $0.631 \mathrm{mg} / \mathrm{l}$. The extraction of copper from an aqueous solution of zinc salt was only $2 \ldots 3 \%$.

\section{COPPER COPRECIPITATION}

To extract copper from zinc, researchers used coprecipitation with hard-soluble zinc phosphate [9]. Zinc phosphate was precipitated at $\mathrm{pH} \mathrm{3}$, and it was found that the greater the zinc phosphate crystals, the less copper was precipitated. Probably the mechanism of codeposition of such copper is either part of the crystals or sorbed by the surface of the crystal. In any case, the smaller the size of the crystals, the more copper coprecipitates. To reduce the size of the crystals, urea was added to the zinc sulfate solution. Copper from the dissolved precipitate was extracted at $\mathrm{pH} 9 \ldots 10$ with carbon tetrachloride as diethyldithiocarbamate. Apparently the disappointing results were obtained that the method of determining copper in zinc sulfate did not work.

The authors of article [10] emphasize that the determination of copper is less than $1 \mathrm{mg} / 1$ in solutions where there are other metals at a concentration of $100 \ldots 150 \mathrm{~g} / 1$ complex problem, but they solved it quite simply, co-planted copper with diethyldithiocarbamates nickel and cobalt. The authors neutralized the sample to $\mathrm{pH} 1 \ldots .5$ with ammonia and added an aqueous reagent solution. The precipitate was dissolved in a mixture of hydrochloric and nitric acids and analyzed. Copper also displaces zinc from the diethyldithiocarbamate complex and is therefore deposited first. We used NaDTC to deposit copper. It is known that the reagent dissolves well in water $\left(3.5 \mathrm{~g}\left(\mathrm{C}_{5} \mathrm{H}_{10} \mathrm{NNaS}_{2} \cdot 3 \mathrm{H}_{2} \mathrm{O}\right)\right.$ per $\left.100 \mathrm{ml}\right)$. Metallic zinc $(10 \mathrm{~g})$ was dissolved in hydrochloric acid (37 ml, $2 \mathrm{M}), 2$ drops of nitric acid were added to accelerate dissolution of the residues. We removed the excess acid, bringing the residue to $50 \mathrm{ml}$ with $\mathrm{pH} 4.5$ $\left(\mathrm{NH}_{3}\right)$. To $20 \mathrm{ml}$ of this solution was added $1 \mathrm{ml}$ of saturated aqueous NaDTC solution, a white precipitate precipitated, which then turned a little yellow. The filter cake was dissolved in $5 \mathrm{ml} \mathrm{HCl}(2 \mathrm{M})+$ one drop of $\mathrm{HNO}_{3}$, evaporated and redissolved in $\mathrm{HCl}$. Excess zinc was removed on a very basic anion exchanger, after ionic purification the copper concentration was $0.4 \ldots 0.5 \mathrm{mg} / 1$ and zinc $5.3 \ldots 5.9 \mathrm{mg} / \mathrm{l}$. We compared different methods of extracting copper from a concentrated solution of zinc salt: at ion-exchange separation on a strongly basic anion exchanger AV-17, the zinc residue was most often $\sim 50 \ldots 60 \mathrm{mg} / \mathrm{l}$, when extracted from NaDTC the zinc residue was $24 . .27 \mathrm{mg} / \mathrm{l}$, when extracted with DAPM - $3.6 \mathrm{mg} / \mathrm{l}$. Thus, when performing the operation of separation into one stage, the DAPM reagent is most effective.

\section{PROSPECTS OF USE OF VARIOUS COPPER AND ZINC COMPOUNDS FOR THEIR DIVISION}

Mosher and Sievers' monograph indicates that copper with trifluoroacetylacetone forms a volatile complex that can be dispersed without decomposition, with the zinc complex being destroyed [11]. We tested the properties of copper and zinc acetylacetonates after their synthesis. Copper forms a complex of blue color very easily with almost $100 \%$ yield, the yield of colorless zinc acetylacetonate is several tens of percent. The optimum $\mathrm{pH}$ for the synthesis of copper acetylacetonate is 5.4, and for zinc is 8.9. Acetyl acetonates of copper and zinc were obtained by reacting aqueous solutions of metal sulfates with acetylacetone by adding ammonia and ethyl alcohol. According to the literature, acetylacetonate of copper is distilled at $236^{\circ} \mathrm{C}$ with decomposition, according to our data, the constancy of mass remains up to $175^{\circ} \mathrm{C}$. Zinc acetylacetonate as if distilled at $350^{\circ} \mathrm{C}$ with decomposition, but according to our experimental data, it begins to decompose already at $80^{\circ} \mathrm{C}$. More volatile complexes give fluorinated $\beta$ diketones.

\section{CONCLUSIONS}

Distillation as a way of separating zinc copper is a promising thing. Distillation of volatile copper compounds and possibly zinc in the future can be introduced to simplify the separation apparatus and conditions. Co-precipitation, ion exchange, and extraction remain important additional methods for separating copper from the zinc matrix.

\section{REFERENCES}

1. N.A. Smith, D.L Bowers, D.A. Ehst. The production, separation, and use of ${ }^{67} \mathrm{Cu}$ for radioimmunotherapy: a review // Applied Radiation and Isotopes. 2012, v. 70, p. 2377-2383.

2. D.A. Ehst, J.L. Willit. Methods for producing Cu-67 radioisotope with use of a ceramic capsule for medical applications // US Patent No. 9312037 B2, Apr.12, 2016.

3. K.B. Kladnitskaya, A.N. Grisevich. To the determination of copper in cadmium and zinc by diethyldithiocarbamate // Ukr. Chem. Jorn. 1961, v. 27, № 6, p. 803-807.

4. A.N. Grisevich, K.B. Kladnitskaya. A quick method for detecting small amounts of copper in zinc and 
cadmium // Factory Laboratory. 1961, v. 27, № 11, p. $1343-1328$.

5. A.K. Babko, L.I. Dubovenko. Chemiluminiscent determination of copper in zinc and high purity alcali // Factory Laboratory. 1964, v. 30, № 11, p. $1325-1328$.

6. F.F. Dyer, G.W. Leddicotte. The radiochemistry of copper // Oak Ridge National Laboratory. April 1961, p. 42-43.

7. V.H. Antonova, I.P. Zhivopiscev Copper determination // Scientific notes of Perm University. 1974, № 324, p. 57-59.
8. Y.A. Mahnev, M.I. Degtev. Chemical spectral determination of copper using three-phase extracting systems // Org. reagents in analytical chemistry. Perm. 1980, Issue 3, p. 69-73.

9. V.T. Chuiko, N.I. Reva. The coprecipitation of trace copper with zinc phosphate from a solution of zinc sulfate // Ukr. Chem. Journ. 1968, v. 34, № 2, p. 193-195.

10. D.F. Makarov, I.S. Ostapchuk. Determination of cobalt in nickel-cobalt sulfate solutions // Factory Laboratory. 2003, v. 69, № 11, p. 22.

11. R. Moshier, R. Sives. Gas chromatography of metal chelates. M.: "Mir", 1967, 175 p.

Article received 18.01.2020

\title{
ИССЛЕДОВАНИЯ ПО ВЫДЕЛЕНИЮ МЕДИ-67, ПОЛУЧЕННОЙ ФОТОЯДЕРНЫМ СПОСОБОМ ИЗ ЦИНКА ПРИРОДНОГО СОСТАВА
}

\author{
А.И. Азаров, В.А. Бочаров, А.Ф. Стоянов
}

В мире планируется производить перспективный для приготовления радиофармпрепаратов радиоизотоп меди-67 по реакции ее получения из цинка-68 под действием $\gamma$-излучения на ускорителе электронов. Следующей по значению проблемой является разделение меди и цинка. Уже подробно исследованы экстракция, ионный обмен и термическая отгонка цинка. Перспективным является соосаждение меди с малым количеством цинка и термическая отгонка органических соединений металлов.

\section{ДОСЛІДЖЕННЯ ПО ВИДІЛЕННЮ МІДІ-67, ОДЕРЖАНОЇ ФОТОЯДЕРНИМ СПОСОБОМ З ЦИНКУ ПРИРОДНОГО СКЛАДУ \\ О.І. Азаров, В.О. Бочаров, О.Ф. Стоянов}

У світі планується виробляти перспективний для виготовлення радіофармпрепаратів радіоізотоп міді-67 по реакції ії одержання з цинку-68 під впливом $\gamma$-випромінювання на прискорювачі електронів. Наступною за значенням проблемою є розділення міді і цинку. Вже докладно досліджені екстракція, іонний обмін та термічна відгонка цинку. Перспективним є співосадження міді з малою кількістю цинку і термічна відгонка органічних сполук металів. 